\title{
Technology and Education - Prospects of a Future Classroom
}

\author{
Sonali Bhandari Jain \\ Assistant Professor, Department of Commerce \\ St. Aloysius College, Jabalpur, Madhya Pradesh, India \\ https://orcid.org/0000-0002-2852-9841
}

Manuscript ID:

EDU-2021-09033839

Volume: 9

Issue: 3

Month: June

Year: 2021

P-ISSN: 2320-2653

E-ISSN: 2582-1334

Received: 16.03.2021

Accepted: 25.04.2021

Published: 01.06.2021

\begin{abstract}
In an age where everything has become more Visual and access to technology and its devices has increased significantly, there is a need to bring about a radical change in how education is imparted and delivered. Using modern age technology, we can not only save resources and time but also make learning more interactive and attractive. This research study was undertaken to ascertain which methodology of teaching works best in the modern-day scenario. Two studies were undertaken.

In the first study, a test was conducted on a group of 40 students of the school who were experimented with by delivering lessons in both modern and traditional teaching methods. After analyzing the results, it was observed that the modern way of teaching is a better source of imparting knowledge as it engages the students and makes them want to learn more.

In the second study, increased use of the internet and a subsequent rise in online education portals is observed, thereby proving that the modern way of teaching holds the key to a better future in the field of education.
\end{abstract}

Keywords: Education, Information age, Innovation, Smart classroom, Technology, Teaching method

\section{Introduction}

The primary trait of human beings that differentiates us from the animal kingdom is our ability to learn and acquire knowledge and use it for our development and betterment. This process of transfer of knowledge from one party to another is called teaching. The ancient techniques included writing on clay tablets with a stick, recitation and drawing pictures on the walls of caves.

Citation:

Jain, Sonali Bhandari.

"Technology and Education

- Prospects of a Future

Classroom." Shanlax

International Journal of

Education, vol. 9, no. 3,

2021, pp. 149-154.

DOI:

https://doi.org/10.34293/

education.v9i3.3839

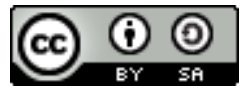

This work is licensed under a Creative Commons Attribution-ShareAlike 4.0 International License As time progressed, the concept of paper, pencils and pens emerged with the teachers writing lessons on a black chalkboard. But, at the advent of the $21 \mathrm{st}$ century, the world witnessed a technological boom that proved to be a total game-changer.

People were now glued to their T.V. screens, Computers and Mobile phones. The reason being that technology gave them a way to see pictures in motion, which was not only more fascinating than the traditional words and pictures printed on paper but also gave a better understanding of the concept and helped them retain that knowledge for a longer period.

\section{Education and the Use of Technology For Students}

Corporations like Apple and Microsoft have always promoted technology for students by making most of their offered products and devices affordable for students.

Apple offers student discounts on its high-end laptops and introduced an affordable range of laptops specially designed for students. Technology is designed to be as limitless as a child's imagination. 
Apple products put complete freedom of expression in the hands of every student who uses them. iPad is simple enough for anyone to master from the start and flexible enough to let students go wherever their ideas take them. Mac provides the power to pursue even the most ambitious projects. (https://www.apple.com/in/education/)

While, Microsoft offers student discounts on one of its widely used products - Microsoft Office. Microsoft Office is a collection of office-related applications. Each application serves a unique purpose and offers a specific service to its users. (Joli Ballew, 2019)

\section{For Teachers}

Educators worldwide, especially in the developed countries like the USA, UK, Australia, etc., have replaced $80 \%$ of their teaching aids and supplies with technological devices such as Tablets for note-taking Projectors and Televisions for delivering lessons.

Teaching is no more local. It has become borderless. All thanks to applications like Skype and Google Hangouts, educators can now deliver their lessons via sessions of video calls which are costeffective as they do not require any infrastructural setup for the educator and can be accessed by the student from anywhere. Since teaching is a personal service that depends on the intellect of an individual, it is hard to find the substitute of an existing good teacher. Hence, the feature of video calling bridges that gap between the student and educator, which would have otherwise snapped due to distance. As observed, Indians are very good at Mathematics. Countries like United States of America are in dire need of good Mathematics teachers. Here's where video calling applications play their vital roles.

Microsoft offers certified courses for modernday educators to get them acquainted with an application that can help them in creating tech-savvy classrooms. The Microsoft Innovative Educator (MIE) Expert program is an exclusive program created to recognize global educator visionaries who are using technology to pave the way for their peers in the effective use of technology for better learning and student outcomes (https://education.microsoft. com/de-at/resource/1703c312)
Similarly, Google has introduced a Google certified educator where the applicant is required to clear certain examinations to get the certificate. Google Certified Educator (GCE) is a program designed and managed by Google for educators who use G Suite for Education as part of their teaching and student learning. The program combines classroom experience with Google-developed training resources and examinations that lead towards certification. (https://sites.google.com/a/ccpsnet.net/edtechhub/ training.../google-certified-educator)

\section{For Institutions}

Most Schools, Colleges have started to realize that bringing in the use of technology in the fields of teaching or even record-keeping for that matter is going to reward them multifold. Premier colleges provide the facility of Distance Learning wherein the student can acquire the requisite degree without leaving the comforts of their home. This is beneficial for those pursuing another course or engaged in a job side by side.

Similarly, colleges have created a forum-like platform wherein the teachers and students can interact on a $24 \times 7$ basis for doubt solving and disseminating important information.

Educators now upload to the LMS their recorded lectures which can be viewed by the student at their convenience. A learning management system (LMS) is a software application or Web-based technology used to plan, implement, and assess a specific learning process. Typically, a learning management system provides an instructor with a way to create and deliver content, monitor student participation, and assess student performance. (wikipedia.org)

Institutions are now switching to online examinations replacing the traditional approach of conducting examinations as it helps in monitoring and assessing the students in a better way. The use of technology while assessing performance reduces human errors, thereby making it more effective and efficient.

\section{Review of Literature}

Instructors have been working to create a more dynamic classroom experience for decades. This has taken shape in experiments with flipped classrooms 
(an instructional strategy where educational content is delivered outside of the classroom, while activities traditionally considered "homework" move into the classroom), as well as a heavy emphasis on group work and peer collaboration.

At the same time, by incorporating digital quizzes and assessments, videos, simulations, and gamification elements into course content, educators can create a dynamic learning experience for each student on an individual level. By capitalizing on the digital habits of students, the classroom can be filled with interactivity regardless of the class size or topic. (Mike Silagadze, Co-Founder and CEO at Top Hat, www.quora.com)

With globalization, the information revolution, and increasing demands for a highly skilled workforce, nations are increasingly prioritizing education. When appropriate IT tools are implemented correctly, a requisite software in the classroom, for example, can allow students to learn at their own pace, and tablets can help children develop important digital skills and computer know-how that they'll need to succeed in our knowledge-based economy. (www.worldbank. org/en/topic/edutech)

Improving education is a huge issue (and always has been). Test scores, our perceived performance against other countries, and other factors have pushed education to the forefront of national politics, right behind healthcare reform. Technology can be used to improve teaching and learning and help our students be successful. Technology can give teachers $\&$ students great resources, new opportunities for learning, ways collaborate \& create, \& save money. Technology is a very powerful tool for education. (Ragan Whiteside, 2011, techlearning.com)

Recent advancements in educational technology (EdTech) are nothing short of amazing. The developments that have emerged in this field are empowering educators to create remarkable learning experiences for today's young minds.

Now, the education field looms on the horizon of positive disruption. New technologies promise to make it easier and faster for students to learn.

A recent poll reveals that $75 \%$ of educators believe that digital content will replace textbooks by the year 2026 , \& there are more remarkable technologies on the way. (Kali B, 2019, elearningindustry.com)

\section{Objectives}

The objectives of this research paper are as under:

- To determine which method of teaching is more interesting and attractive for students.

- To find which method of teaching provides a better understanding of the topic delivered.

- To ascertain which method of teaching helps in retaining the information given for a longer period.

- To measure the effectiveness of online or E-education.

The research paper was conducted to test the undertaken hypothesis.

Hypothesis - Modern practices of imparting education are better than the Traditional approach of imparting education.

Using this hypothesis as the basis, we will test whether the undertaken hypothesis is true or false.

\section{Limitations of Study}

As always, there exist some limitations in all the studies that are conducted. Following are the three limitations that might be contained in this research paper:

Time: There is never enough time to conduct flawless research as there exist inherent limitations such as time deadlines.

Primary Data: Major findings of research study 2 rely on the primary data collected by the author. The drawbacks of primary data are that the information provided by the individual might be incorrect or incomplete. There might exist a communication gap in which the person conducting the experiment might not convey his/her questions in a clear way which gives rise to receiving incorrect information. At times it has also been observed that people give hypothetical answers just for answering, which contributes to receiving incorrect data.

Secondary Data: The data available on the Internet, which is the biggest source of secondary data for this research paper, might be false or not from trusted sources. Hence, its reliability is generally low.

\section{Research Study}

The findings of this study are based solely on Primary Data that was collected by the author. 


\section{Sample Size}

A study was conducted in Billabong High International School, Jabalpur, Madhya Pradesh. The total strength of the school is 352 students, out of which the study was conducted on a group of 40 students, which is approximately $10 \%$ of the total population. This study was done in Jan 2020.

\section{The Experiment}

Over one week from Jan 4th to 9th, 40 students have explained 2 topics of Environmental Science, namely Heritage of India and Adaption in animals. Both the topics were delivered by the teacher for 3 days each. At the start of next week, the knowledge on both topics was assessed via a class test.

For the first topic, various IT tools were used by the teachers to discuss the rich heritage of India. The various dance forms practiced in India were shown through a video using the TVs placed in the classrooms. Teachers also told the students to visit certain websites at their homes related to the topic. They were also encouraged to prepare a one-minute PowerPoint presentation showing their knowledge on various sub-topics such as the national animal, fruit, sport of India, the languages spoken and various foods consumed in different regions of India.
For the second topic, the teacher delivered her lesson using the traditional method, i.e., reading out loud the topic from the reader and giving questions and answers on the same on the blackboard.

At the start of the next week, on a span of 2 days, the students were given a class test on both topics. This test consisted of Fill ups, Match the following, Identify the picture and Describe in detail questions.

When the papers were assessed, it was observed that the students performed better in the first topic, i.e., Heritage of India, which was aided by the use of IT tools in comparison to the second topic, which used traditional methods of delivering a lesson. Students were able to identify pictures of dance forms in a better way as they were shown videos of the same and the preparation of a PowerPoint slide not only helped them retain the knowledge better but also encouraged them to search for more information on search engines like Google to make their presentation look my informative and attractive. This helped them in acquiring an in-depth knowledge of the topic, which was otherwise not give in their textbooks.

After the assessment of papers, The results are shown through the table below:

\section{Descriptive Statistics}

\begin{tabular}{|c|c|c|c|c|c|c|c|c|}
\hline $\begin{array}{c}\text { Category of } \\
\text { Students }\end{array}$ & N & Range & Minimum & Maximum & \multicolumn{2}{|c|}{ Mean } & $\begin{array}{c}\text { Std. } \\
\text { Deviation }\end{array}$ & Variance \\
\cline { 2 - 9 } & Statistic & Statistic & Statistic & Statistic & Statistic & Std. Error & Statistic & Statistic \\
\hline A & 20 & 5.00 & 10.00 & 15.00 & 12.3500 & .31851 & 1.42441 & 2.029 \\
\hline B & 20 & 5.00 & 14.00 & 19.00 & 16.5500 & .25624 & 1.14593 & 1.313 \\
\hline Valid N (listwise) & 20 & & & & & & & \\
\hline
\end{tabular}

For the assessment of papers, we divided 40 students into groups. Each group has 20 students. Group A belongs to the traditional method and group $\mathrm{B}$ belongs to the modern teaching method. After the assessment, we find that the mean and standard deviation of marks is more in the B group. Even S.D. is also shown a good result consistency in the B group. Through the variance, group B having a favorable result. Hence, the hypothesis undertaken stands to be true, that is, Modern practices of imparting education are better than the Traditional approach of imparting education.
After the assessment of papers, students were asked various questions relating to their experiences. The results are shown through the table below:

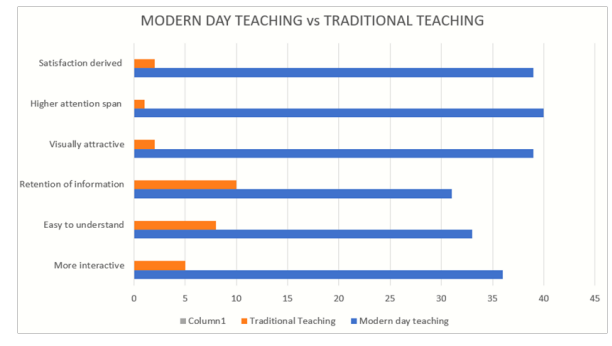


Table 2: Final Assessment, Billabong High

International School, 2019 - Modern-Day

Learning vs. Traditional Learning (Group of 40 Students)

\begin{tabular}{|l|c|c|}
\hline & $\begin{array}{c}\text { Students } \\
\text { voting in } \\
\text { favour of } \\
\text { Modern-day } \\
\text { learning }\end{array}$ & $\begin{array}{c}\text { Students } \\
\text { voting in } \\
\text { favour of } \\
\text { Traditional } \\
\text { learning }\end{array}$ \\
\hline More interactive & 36 & 4 \\
\hline Easy to understand & 32 & 8 \\
\hline Retention of information & 30 & 10 \\
\hline Visually attractive & 38 & 2 \\
\hline $\begin{array}{l}\text { Higher attention span } \\
\text { while the lecture is } \\
\text { being delivered }\end{array}$ & 39 & 1 \\
\hline $\begin{array}{l}\text { Satisfaction derived } \\
\text { from the delivered } \\
\text { lecture }\end{array}$ & 39 & 1 \\
\hline
\end{tabular}

From the above table and chart, it is clear that when the educator used IT tools for imparting knowledge. The students not only grasped the topic in a better way but were also more enthusiastic and showed more interest in participating in various class activities. Hence, the hypothesis undertaken stands to be true, that is, Modern practices of imparting education are better than the Traditional approach of imparting education.

\section{Research Study 2}

Findings of this study are based solely on the secondary data that was collected with the use of the internet by the author.

\section{Observations}

The usage of the Internet has increased significantly across the globe. The picture given below depicts the survey that was conducted in the year 2016 showing the top 10 countries which use the internet the most (Source: YouTube):

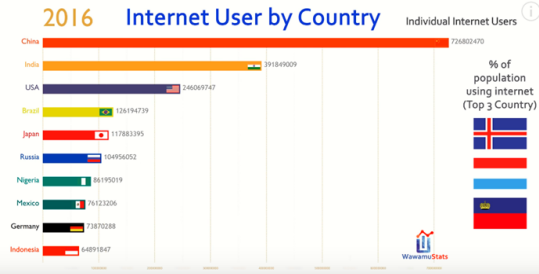

As the usage of the internet and technology has increased, educators have found new ways to impart knowledge that has not only benefited the students but also to them in terms of monetary earnings. Websites like YouTube, Coursera, Udemy, Byju's etc are some of the popular applications where educators and students can interact for mutual benefits. Usage of these websites has increased significantly as they can be accessed by students anytime, anywhere.

Science is the most taught subject as it required the most amount of visualization compared to other subjects. Even preparation for Competitive exams such as UPSC, CDS, CA, CS, etc., via online courses has increased significantly. The undertaken study observes the top 10 Indian Youtubers who have opened their channels on YouTube to teach various subjects such as Science, Maths, Languages, etc.

Table 2: Top 10 Indian YouTubers and their Rankings

\begin{tabular}{|c|c|c|c|}
\hline & Subject(s) taught & $\begin{array}{l}\text { No. of } \\
\text { videos } \\
\text { upload }\end{array}$ & $\begin{array}{l}\text { Total no. } \\
\text { of views }\end{array}$ \\
\hline eDewcate & Nursery Rhymes & 282 & $\begin{array}{l}326.71 \\
\text { million }\end{array}$ \\
\hline $\begin{array}{l}\text { Arvind } \\
\text { Gupta }\end{array}$ & $\begin{array}{l}\text { Experiments for } \\
\text { Pre-teens and teens }\end{array}$ & 5350 & $\begin{array}{c}35.68 \\
\text { million }\end{array}$ \\
\hline Unacademy & $\begin{array}{l}\text { Civil Services, JEE, } \\
\text { NEET, AIIMS }\end{array}$ & 323 & $\begin{array}{l}29.25 \\
\text { million }\end{array}$ \\
\hline TutorVista & $\begin{array}{l}\text { physics, chemistry, } \\
\text { biology, maths }\end{array}$ & 951 & $\begin{array}{c}16.91 \\
\text { million }\end{array}$ \\
\hline Meritnation & $\begin{array}{l}\text { All CBSE subjects } \\
\text { for classes } 1 \text { to } 10\end{array}$ & 207 & $\begin{array}{c}1.91 \\
\text { million }\end{array}$ \\
\hline $\begin{array}{l}\text { The Curious } \\
\text { Engineer }\end{array}$ & $\begin{array}{l}\text { Engineering related } \\
\text { subjects }\end{array}$ & 44 & $\begin{array}{l}1.03 \\
\text { million }\end{array}$ \\
\hline Arun Kumar & Photoshop Tutorials & 603 & $\begin{array}{c}2.84 \\
\text { million }\end{array}$ \\
\hline $\begin{array}{l}\text { Pretty } \\
\text { Uzlain }\end{array}$ & $\begin{array}{l}\text { Quantitative } \\
\text { Aptitude }\end{array}$ & 59 & $\begin{array}{c}1.29 \\
\text { million }\end{array}$ \\
\hline $\begin{array}{l}7 \text { Active } \\
\text { Studio }\end{array}$ & $\begin{array}{l}\text { 2D and 3D } \\
\text { augmentation of } \\
\text { science diagrams }\end{array}$ & 99 & $\begin{array}{l}755.45 \\
\text { thousand }\end{array}$ \\
\hline $\begin{array}{l}\text { Dr. Praveen } \\
\text { Chaudhary }\end{array}$ & Medical subjects & 363 & $\begin{array}{c}12.44 \\
\text { thousand }\end{array}$ \\
\hline
\end{tabular}

From the above table, we can observe the rising trend of using online mode to acquire education across various fields ranging from Nursery Rhymes to preparation for competitive exams. 


\section{Conclusion and Further Scope for Research}

To cope up with the changing times, modern-day individuals must be given modern-day skills. In this dynamic environment, one cannot afford to remain reactive and must strive to remain proactive.

This principle needs to be applied in the field of education as well. The new generation reacts to IT tools and their use better than the old prevalent penpaper teaching. Educators across the globe must train themselves to make use of technology in such a way that it can aid them in their classrooms. It not only makes the classroom experience of their students fun and engaging but also helps in saving time and resources. It makes the impossible possible (learning via video call sessions). Also, the use of the internet and technology opens up new dimensions for the personal growth of the educator himself as providing online classes or starting a YouTube channel helps them to grow financially.

With the conducted research studies, there is a need to realize that a change is required in the way we impart education because most schools and colleges, especially in a country like India, teachers are reluctant to change as they lack proper training regarding the use of technology and its tools.

With that being said, another argument might be brought up as to where and to what degree technology must be used in education. And whether there are still some areas of education that require the traditional approach to be followed. Also, given that developing countries like India and China, where the resources are less but the population is more, how exactly can traditional cost-effective ways of imparting education be replaced by modern-day teaching using technology? These are some of the questions which need to be answered. But, all in all, technology and education go hand in hand and can work wonders when teamed up together.

\section{References}

"Age-old Teaching Methodology of the Indian Education System vs Modern Learning." Senses, https://senseselec.com/blogs/age- old-teaching-methodology-of-the-indianeducation-system-vs-modern-learning/

Anderson, Jonathan. "IT, e-learning, and Teacher Development." International Education Journal, vol. 5, no. 5, 2005, pp. 1-14.

"Apple and Education." https://www.apple.com/in/ education/

Ballew, Joli. "A Complete Guide to Microsoft Office." Lifewire, 2019.

Begum, Salma. "Traditional Method of Teaching vs Modern Method of Teaching - A Comparative Analysis at Bangalore Private School." International Education and Research Journal, vol. 2, no. 11, 2016.

"Computer Based Learning." K12 Academics, https://www.k12academics.com/pedagogy/ computer-based-learning\#.V152QNIrLIV

Dadan. "Educational Technology and Other Learning Resources." Trans23 Blog, 2010.

"Digital Technologies in Education." World Bank, https://www.worldbank.org/en/topic/edutech

Kali, B. "The Future of Education and Technology." elearningindustry.com, 2019.

Mehta, Sujata. "Modern Teaching Methods - It's Time for the Change." Eduvoice, https:// eduvoice.in/modern-teaching-methods/

"Microsoft Innovative Educator (MIE)-Programme: MIE Expert." Microsoft, https://education. microsoft.com/de-at/resource/1703c312

"Mike Silagadze." https://www.quora.com/profile/ Mike-Silagadze-2

Savita, Srivastava. "A Study of Multimedia \& Its Impact on Students' Attitude." International conference on Technology Enhanced Education, 2012.

"Teaching Methods: Traditional vs Modern." Stephen Perse, 2017.

"Top 10 YouTube Indian Channels making wave in Education Genre." Vidooly, https://vidooly. com/blog/top-10-youtube-indian-channelsmaking-wave-in-education-genre

Whiteside, Ragan. "How Technology can Help Improve Education." techlearning.com, 2011.

\section{Author Details}

Dr. Mrs. Sonali Bhandari Jain, Assistant Professor, Department of Commerce, St. Aloysius College, Jabalpur, Madhya Pradesh, India, Email ID: sonalijain7447@yahoo.com 